\title{
АНТИАБОРТНАЯ ПОВЕСТКА В КОНСЕРВАТИВНОМ ДИСКУРСЕ СОВРЕМЕННОЙ РОССИИ: ИДЕОЛОГИЧЕСКИЕ КАМПАНИИ, ПРАВОВЫЕ ИНИЦИАТИВЫ И РЕГИОНАЛЬНЫЕ ПРАКТИКИ
}

\author{
ЖАННА ЧЕРНОВА, ЛАРИСА ШПАКОВСКАЯ
}

\begin{abstract}
В статье рассматриваются процессы консервативной мобилизации в России в 2000-2010 г2. как разворачивания пропагандистских идеологических кампаний, направленных на решение демографических проблем, прежде всего на увеличение рождаемости, с использованием консервативной риторики традиционной семьи, традиционных ценностей и традиционных гендерных ролей. Основным исследовательским фокусом статьи является дискурс об абортах. Государственная антиабортная пропаганда рассматриваются как «лакмусовая бумажка» происходящих процессов ретрадищионализации государственной идеологии и инструментов регулирования репродукции и сексуальности. Анализируя законодательные и региональные инициативы антиабортной направленности, авторы выделяют набор основных действующих публичных акторов регионального и федерального уровня, а также используемую ими риторику. В статье показано, что начиная с 2000-х годов одним из ведущуих акторов, выступаюших за отмену права на аборт, является Русская православная церковь (РПЦ). На федеральном уровне присутствуют публичные акторы, которые сдерживают принятие антиабортного законодательства и разворачивают последовательную критику противоабортной риторики. В то время как на региональном уровне акторы - проводники консервативной мобилизации более эффективно опираются на государственную поддержку, не встречая заметной критики в свой адрес. Содержательно антиабортная риторика вписана в дискурс демографических проблем $и$ сокращения численности населения как угрозы наџиональной безопасности страны. Она нацелена на регулирование поведения граждан в сфере интимности, их телесности и морального облика, таким образом представляя собой вариант биополитики в терминах Мишеля Фуко. В этом смысле конечной иелью консервативной мобилизации являются управляемые граждане, индоктринированные идеологией традиционно семейного образа жизни и многодетности.
\end{abstract}

Ключевые слова: антиабортная риторика, консерватизм, рождаемость, традиционнье семейные ценности, анализ дискурса.

\section{ВВЕДЕНИЕ}

С середины 2000-х годов в российском политическом дискурсе происходит отчетливое усиление консервативного тренда, что особенно заметно на примере политизации вопросов брачно-репродуктивного поведения граждан (Захаров 2012; Сакевич, Денисов, РивкинФиш 2016).

ЖАННА ВЛАДИМИРОВНА ЧЕРНОВА (chernova30@mail.ru), СОЦИОЛОГИЧЕСКИЙ ИНСТИТУТ РАН — ФИЛИАЛ ФЕДЕРАЛЬНОГО ГОСУДАРСТВЕННОГО БЮДЖЕТНОГО УЧРЕЖДЕНИЯ НАУКИ ФЕДЕРАЛЬНОГО НАУЧНОИССЛЕДОВАТЕЛЬСКОГО СОЦИОЛОГИЧЕСКОГО ЦЕНТРА РОССИЙСКОЙ АКАДЕМИИ НАУК, РОССИЯ.

ЛАРИСА ЛЕОНИДОВНА ШПАКОВСКАЯ (slarisalarisa@gmail.com), СОЦИОЛОГИЧЕСКИЙ ИНСТИТУТ РАН ФИЛИАЛ ФЕДЕРАЛЬНОГО ГОСУДАРСТВЕННОГО БЮДЖЕТНОГО УЧРЕЖДЕНИЯ НАУКИ ФЕДЕРАЛЬНОГО НАУЧНОИССЛЕДОВАТЕЛЬСКОГО СОЦИОЛОГИЧЕСКОГО ЦЕНТРА РОССИЙСКОЙ АКАДЕМИИ НАУК, РОССИЯ.

СТАТЬЯ ПОСТУПИЛА В РЕДАКЦИЮ В АПРЕЛЕ 2021 Г. 
Она приобретает смысл «возрождения традиций» и «сохранения традиционных семейных ценностей», связана с критикой либерального гендерного дискурса и носит ярко выраженный антизападный характер. В качестве примера можно привести пропагандистские кампании, направленные на ограничение репродуктивных прав женщин, против введения ювенальной юстиции, на запрет пропаганды гомосексуальности (Муравьева 2014).

Консервативный поворот, происходящий в современных обществах в последние годы, имеет как глобальное, так и локальное измерение и представляет собой сложно организованное явление. С одной стороны, он разворачивается в более широком контексте индивидуализации и плюрализации гендерных отношений и жизненных биографий. Эти изменения концептуализируются такими теориями, как теория рефлексивной модернизации (Giddens 1991), общества риска (Бек 2000), второго демографического перехода (Van de Каa 1987). Они постулируют усиление индивидуализации, роли выбора и рефлексивности в современных обществах. Иначе говоря, они обращают внимание на то, что все аспекты человеческой биографии становятся предметом индивидуального выбора, а не следования традиции. Применительно к браку и репродукции это означает трансформацию их смысла, приобретает свойства личных, планируемых и сознательных решений и выборов (Гидденс 2004). Социальные теоретики также обращают внимание на возрастающую значимость политического дискурса, экспертного знания и СМИ в формировании социальной рефлексивности через определение нормативных моделей поведения, в том числе в сфере семьи и репродукции (Giddens 1991; Illouz 2008).

С другой стороны, традиционная гендерная идеология и акторы, продвигающие данную повестку, становятся более влиятельными в поле публичной политики. Консервативный дискурс в самых разных контекстах выстраивается вокруг необходимости ужесточения контроля за женской репродукцией и наделения женщин ответственностью за воспроизводство нации (Yuval-Davis 1997; Roche 2016; Graff, Ratna, Walters 2019). Гетеросексуальный брак, который интерпретируется как условие высокой рождаемости, становится точкой сборки консервативного гендерного порядка. Формирование консервативной повестки в сфере семьи и демографии предполагает не только нормализацию гетеросексуального брака в качестве нормативной модели семьи, но и аккумулирование различного рода ресурсов акторами, которые активно участвуют в консервативной мобилизации (региональные исполнительные власти, РПЦ (Русская православная церковь), ГОНГО (Государством организованные негосударственные организации)). Вопрос о том, каким образом консервативная мобилизация происходит в современном российском обществе, насколько локальный сценарий вписывается в глобальные тенденции, нуждается в более внимательном изучении.

В данной статье мы анализируем процессы консервативной мобилизации как набор пропагандистских идеологических кампаний, направленных на решение демографических проблем и, прежде всего, на увеличение рождаемости, с использованием консервативной риторики «традиционной семьи», «традиционных семейных ценностей» и традиционных гендерных ролей. Нас также интересует, какое место занимает антиабортная риторика в процессе разворачивания дискурса консервативной мобилизации. 
Для изучения консервативной мобилизации мы анализируем публикации в региональных и федеральных СМИ за 2000-2010 гг. Публикации отбирали, используя электронную базу ИНТЕГРУМ, по ключевым словам «аборт», «антиабортный», «против абортов», «право на аборт». На первом этапе были автоматически отобраны все публикации по данным ключевым словам, доступные в электронном архиве наиболее авторитетных российских СМИ ИНТЕГРУМ. Затем из массива найденных базой статей исследователи удалили публикации, не имеющие отношения к дискурсу власти. То есть в выборку попали только публикации, описывающие действия представителей региональных, федеральных властей и РПЦ, а также транслирующие высказывания и речи представителей властей всех уровней. Кроме того, в базу эмпирических материалов вошли только статьи, для которых проблема абортов является центральной по смыслу. База материалов для дискурсивного анализ была дополнена законодательными документами, имеющими отношение к демографии и здоровью (поиск документов осуществляли с использованием базы данных Консультант+). Дополнительно в нашу базу материалов вошли публикации, представляющие экспертный дискурс в области социальных наук и демографии по проблеме рождаемости. Дискурсивный анализ осуществляли с применением метода тематического анализа (Flick 2006).

\section{КОНСЕРВАТИВНАЯ МОБИЛИЗАЦИЯ В РОССИЙСКОМ ПОЛИТИЧЕСКОМ ДИСКУРСЕ}

Консервативная мобилизация в России в сфере семьи и репродукции обосновывается демографической ситуацией, которую переживает современное российское общество (Вишневский 2012a, b; Вишневский, Захаров 2019; Vishnevsky, Sakevich, Denisov 2018; Rivkin-Fish 2013). Институциональный дизайн и инструменты семейной политики в современной России сконцентрированы преимущественно на монетарных поддержках родительства, уделяют меньшее внимание развитию инфраструктуры заботы о детях, а также оставляют на периферии внимания государства социальные и экономические проблемы родителей, такие как социализация в новой родительской роли, социальная изоляция женщин в период активного материнства, снижение конкурентоспособности молодых матерей на рынке труда (Chernova 2012a; Чернова 2012b; Шпаковская 2012, 2013; Ярская-Смирнова 2010). Консервативная идеология, направленная на формирование и поддержание мифа о благополучной многодетной семье, противоречит сложившейся за десятилетия советской власти модели профессионального, семейного и репродуктивного поведения женщин: малодетность, высокий уровень участия женщин в оплачиваемой занятости, высокая разводимость и как следствие большое число материнских семей, где женщина является единственным кормильцем (Здравомыслова, Темкина 2003; Роткирх, Темкина 2007; Печерская 2012).

Консервативная мобилизация в ее сегодняшнем виде стала возможна благодаря тем социальным, политическим и культурным трансформациям позднесоветского общества 1980-х годов, которые по сути представляли собой «консервативную революцию» (Магун 2010). Актуализация консервативного дискурса во внутренней политике государства была связана с обсуждением проблем демографии (Сакевич, Денисов, Ривкин-Фиш 2016). 
В 2006 г. Президент РФ В.В. Путин в своем послании Федеральному собранию констатировал, что демографические проблемы в обществе, связанные с уменьшением рождаемости, являются результатом распространения среди молодежи внесемейных ценностей ${ }^{1}$. Этот тезис обосновывал необходимость возрождения «традиционных семейных ценностей» и «традиционной семьи» как необходимого условия повышения рождаемости. Концепция государственной политики в отношении молодой семьи определяет в качестве цели семейной политики популяризацию в обществе, особенно в молодежной среде, «духовно-нравственных ценностей дореволюционной семьи» ${ }^{2}$. Знаковым событием для раскручивания консервативной мобилизации явилось учреждение в 2008 г. Дня семьи, любви и верности (8 июля) под покровительством Петра и Февронии канонизированных символов христианского брака.

Кроме символического укрепления традиционной семьи, государство предпринимало попытки поддерживать данный нормативный образец экономическими мерами. Так, например, в 2012 г. в Закон о государственной социальной помощи были внесены дополнения, предусматривающие «для малоимущих граждан, многодетных семей, семей, воспитывающих детей-инвалидов...» ${ }^{3}$ введение безвозмездных ссуд на организацию семейного бизнеса. Согласно этому закону семья, которая может претендовать на подобные ссуды, должна быть официально зарегистрированной, полной и многодетной, т. е. иметь не менее двух детей. В Концепции государственной семейной политики в РФ до 2025 г. $^{4}$ акцент делается на экономическом благополучии родителей как основы стабильной семьи и социальной стабильности в целом. Такая риторика наглядно демонстрирует, что в государственной перспективе родители (в первую очередь матери) являются не субъектом политики, а ее инструментом, который в случае правильного использования должен способствовать поддержанию эффективной реализации государственных задач по обеспечению экономической и социальной стабильности общества. Государственный инструментализм в отношении семьи выражается также в публичных обсуждениях возможности введения таких дисциплинирующих мер, как повышение пошлины на развод, введение налога на бездетные супружеские пары, не имеющие, но способные иметь детей, сокращение показаний к социальным абортам.

\footnotetext{
${ }^{1}$ Послание Президента Российской Федерации Федеральному Собранию Российской Федерации от 10.05.2006 (2006). Консультант-Плюс. URL: http://base.consultant. $\mathrm{ru} /$ cons/cgi/online.cgi?req=doc; base $=\mathrm{LAW} ; \mathrm{n}=60109$

${ }^{2}$ Концепция государственной политики в отношении молодой семьи, утвержденная 8 мая 2007 г. Министерством образования и науки РФ. URL: http://www.consultant.ru/document/cons_doc_LAW_98438/

${ }^{3}$ Федеральный закон «О государственной социальной помощи» от 17.07.1999 №178-ФЗ. КонсультантПлюс. URL: http://www.consultant.ru/document/cons_doc_LAW_23735/

${ }^{4}$ Распоряжение Правительства РФ от 25.08.2014 №1618-р «Об утверждении Концепции государственной семейной политики в Российской Федерации на период до 2025 года». URL: http://www.consultant.ru/document/cons_doc_LAW_167897/
} 


\section{АНТИАБОРТНАЯ РИТОРИКА5 КАК СИМВОЛИЧЕСКИЙ ИНДИКАТОР РОССИЙСКОГО КОНСЕРВАТИЗМА}

Постепенное нарастание консервативных тенденций в российском обществе начинается с 2000-х годов при активном участии РПЦ, которая задает рамку обсуждения моральнонравственных вопросов, выступая в качестве главного транслятора традиционных взглядов на отношения между полами. Современное прочтение традиционных семейных ценностей по сути выступает синонимом антиабортной позиции. Проблема абортов является лакмусовой бумажкой происходящих процессов ретрадиционализации государственной идеологии и инструментов регулирования сексуальности.

При активной поддержке руководства РПЦ была введена такая мера, как «неделя тишины», которая практикуется с 2011 г. Тогда же был принят Закон «Об основах охраны здоровья граждан РФ» ${ }^{6}$, который, в частности, регламентирует порядок проведения абортов. Женщинам, которые решили сделать аборт, в зависимости от срока беременности предлагается подождать от двух до семи дней. В течение этого времени их должен осмотреть гинеколог, на УЗИ им показывают плод, дают послушать его сердцебиение, проводят консультацию психолога. Введение этой меры вызвало противоречивую реакцию со стороны общества. Феминистские организации выступали против использования такого воздействия на женщин, считая это способом принуждения к принятию решения о рождении ребёнка ${ }^{7}$. Несмотря на эти выступления, «неделю тишины» стали активно применять в государственных медицинских учреждениях.

Примерно с начала 2010-х годов активно ведутся политические дискуссии об ограничении доступа к абортам (Сакевич, Денисов, Рывки-Фиш 2016). Руководство РПЦ неоднократно высказывалось за вывод абортов из системы ОМС. Оно регулярно обращается к представителям федеральной власти с требованием ограничить репродуктивные права женщин, оставив возможность проведения аборта только на платной основе. Эту позицию поддерживают ряд консервативно настроенных официальных лиц. Наиболее ярким примером является позиция Уполномоченной по правам ребенка А. Кузнецовой: «Я мечтаю, чтобы было время, когда ни одна женщина не намеревалась и даже мысли не возникло, чтобы сделать аборт» ${ }^{8}$. Для этого, по ее мнению, необходимо расширить практики помощи женщинам, которые находятся в кризисной ситуации и собираются делать аборт. Помимо телефона доверия, юридической и психологической помощи женщинам, детский омбудсмен добилась, чтобы уроки семейного счастья (курс

\footnotetext{
${ }^{5}$ Под антиабортной риторикой мы понимаем систему интерпретаций, аргументирующую полный запрет или существенное ограничение права женщин на проведение медицинской процедуры по искусственному прерыванию беременности.

${ }^{6}$ Федеральный закон «Об основах охраны здоровья граждан РФ» от 20.11.2011 №323-Ф3.

URL: http://www.consultant.ru/document/cons_doc_LAW_121895/

${ }^{7}$ Радулова Н. (2011). Мое тело-мое дело. Огонёк, 36, 52. URL: https://www.kommersant.ru/doc/1763592

8 Анна Кузнецова рассказала о планах по решению проблемы абортов в России (2019). РИА Новости, 10.01.2019. URL:

https://ria.ru/20190110/1549193777.html?fbclid=IwAR3hCNCJzhix0FJas1jcHPjc1_xaBugG8XiVHjAgZsjaBHKvi_i21yMIXQ
} 
«Семьеведение» в общеобразовательных школах) вошли в План десятилетия детства, который реализуется в России с 2018 по 2027 г.

Более умеренную позицию, не поддерживающую полный запрет абортов, занимают представители Министерства здравоохранения и медицинского сообщества. Она связана с опасением, что запрет приведет к росту числа криминальных абортов и негативным последствиям: увеличению показателей материнской и младенческой смертности 9 Экономическая целесообразность запрета, на которой настаивают консерваторы, отрицается руководством Минздрава.

В сентябре 2018 г. Следственный комитет (СК) РФ выступил с инициативой ввести термин «плод человека» в статью 124.1 Уголовного кодекса РФ для того, чтобы можно было бы применять уголовную ответственность за гибель ребенка до его рождения. В нынешней редакции УК РФ такого термина не существует и плод человека не является субъектом уголовного права. Позиция СК РФ обусловлена тем, что «в последнее время к нам поступает много жалоб, и мы возбуждаем уголовные дела и процессуальные проверки по факту смерти плода, в том числе и во время родов. Зачастую судебно-медицинские эксперты устанавливают прямую причинно-следственную связь между действиями врачей и гибелью плода. Но так как плод еще не отделился от матери, то по закону гибель до момента рождения не попадает под статьи УК, и мы не можем привлечь $к$ ответственности врачей за ненадлежащее оказание помощи при родовспоможении и вынуждены прекращать уголовное преследование» ${ }^{10}$. Профессиональное медицинское сообщество выступило с резкой критикой этого предложения, ссылаясь на возможность необоснованного уголовного преследования врачей. Несмотря на то, что официально предложение СК РФ сделать плод человека субъектом уголовного права связано с попытками ввести наказание за халатность врачей и не связно с антиабортной риторикой, на практике введение этой юридической нормы может быть использовано противниками абортов как механизм давления на врачей и принуждения их к отказу от этой медицинской процедуры.

В августе 2018 г. депутат Законодательного собрания Санкт-Петербурга А. Цивилев обратился в Министерство здравоохранения РФ с предложением запретить возможность воспользоваться процедурой ЭКО незамужним женщинам. Депутат считает, что эта процедура должна быть доступна только для тех женщин, кто состоит в официально зарегистрированном или гражданском браке. На данный момент Минздрав рассматривает это обращение. Несмотря на то, что непосредственно данная инициатива не связана с запретом абортов, она, тем не менее, также иллюстрирует консервативный подход в современной российской семейной политики, цель которой не просто повышение рождаемости, а поддержка рождений детей у «правильных» с точки зрения государства родителей.

\footnotetext{
${ }^{9}$ Вероника Скворцова: в нашей стране уже есть негативный опыт полного запрета абортов. ТАСС. Интервью. 3.10.2016. https://tass.ru/interviews/3672086 (Дата обращения 01.07.2021)

${ }^{10}$ Следственный комитет на защите прав. Мед новости, 13 сентября, 2018

https://medportal.ru/mednovosti/sledstvennyy-komitet-na-zaschite-prav-ploda/ (Дата обращения 26.03.2021).
} 
25 января 2019 г. депутат Государственной думы (ГД) В. Милонов выступил с инициативой приравнять аборт к убийству и ввести за него уголовное наказание: «Не надо прикрываться нейтральными терминами типа "прерывание беременности" или "нежелательный плод". Это убийство человека, находящегося в утробе матери, и точка» ${ }^{11}$.

По статистике происходит снижение числа абортов: в 2010 г. в России было зарегистрировано 1186,1 тыс. абортов, а в 2019 г. - уже 621,7 тыс. (включая выкидыши) ${ }^{12}$. Заместитель министра здравоохранения Т. Яковлева отметила, что влияние на ситуацию с абортами оказало информирование женщин: в каждой женской консультации организованы центры психологической и социальной поддержки беременных ${ }^{13,14}$. Демографы, однако, главной причиной снижения количества абортов называют распространение современной контрацепции среди россиян (Вишневский, Денисов, Сакевич 2017).

13 февраля 2019 г. в ГД РФ создана рабочая группа под руководством П. Толстого для обсуждения законодательных инициатив, предложенных РПЦ. Один из ключевых вопросов - предложение вывести аборты из системы ОМС, с которым руководство РПЦ регулярно обращается к власти. Риторика главы РПЦ выстраивается вокруг правовых (право нерожденного ребенка на жизнь) и экономических (использование средств налогоплательщиков) аргументов. Во время открытия Рождественских парламентских встреч в ГД РФ глава РПЦ назвал проблемой оплату налогоплательщиками абортов, совершенных не по медицинским показаниям (названа цифра в 5 млрд рублей в год) ${ }^{15}$. В связи с этим он отметил, что следует признать право на жизнь за нерождённым ребёнком: «Напомню, что право на жизнь, гарантированное Конституцией России, должно подразумевать ее защиту с момента зачатия. Любые формы посягательства на жизнь человека, в том числе аборт, являются нарушением этого правила». Глава РПЦ регулярно выступает с предложениями вывести из ОМС аборты, совершаемые не по медицинским показаниям. Так, например, в своем выступлении на открытии Рождественских парламентских встреч в ГД РФ 30.01 .2019 он говорил: «вынужден сказать, что законодательные изменения в этом вопросе не произошли. До сих пор налогоплательщик

\footnotetext{
${ }^{11}$ Милонов предложил приравнять аборты к убийствам (2019). РИА Новости, 25.01.2019 URL: https://ria.ru/20190125/1549887529.html?fbclid=IwAR1Ktf5pIc4-REqvbyoI-

abnR4CzMZTCqbgrbvWm92FGIKLVPKZ0vjC8plA

12 Единая межведомственная информационно-статистическая система (ЕМИСС). URL: https://fedstat.ru/indicator/31595

${ }^{13}$ В минздраве выступили против запрета абортов (2019). Правмир, 15.02.2019. URL: https://www.pravmir.ru/v-minzdrave-vyistupili-protiv-zapreta-abortov/?fbclid=IwAR3mDslWBMczxP63WNfb5Yb24OIrOXcfTVEtKECjlmGmqeLkejBYmnstWc

${ }^{14}$ В минздраве выступили против запрета абортов (2019). Правмир, 15.02.2019. URL: https://www.pravmir.ru/v-minzdrave-vyistupili-protiv-zapreta-abortov/?fbclid=IwAR3mDslWBMczxP63WNfb5Yb24OIrOXcfTVEtKECjlmGmqeLkejBYmnstWc

15 Слово святейшего Патриарха Кирилла на открытии VI Рождественских парламентских встреч в Совете Федерации (2016). Международные рождественские образовательные чтения, 29.01.2016.

URL: https://mroc.pravobraz.ru/slovo-svyatejshego-patriarxa-kirilla-na-otkrytii-iv-rozhdestvenskix-parlamentskixvstrech-v-sovete-federacii/
} 
платит за то, что медициской помощьюю не является и являться не может: за то, чтобы бесплатно избавиться от нежелательного ребёнка» ${ }^{16}$.

Отвечая на запрос со стороны консервативного лобби, Министерство здравоохранения пересмотрело список показаний к аборту на поздних сроках по ОМС. В декабре 2020 г. на Федеральном портале законопроектов был размещен проект приказа «Об утверждении перечня медпоказаний для искусственного прерывания беременности», который сокращал перечень таких показаний с точки зрения как здоровья женщины, так и нарушений плода. Данный проект был вынесен на общественное обсуждение и вызвал критику со стороны феминистки ориентированных общественных деятелей и организаций ${ }^{17}$, в то время как медицинские эксперты утверждали, что значимых изменений в существовавший ранее список показаний (принятый в 2007 г.) не было внесено ${ }^{18}$.

Успешность и эффективность РПЦ в качестве «разработчика» консервативной идеологии обусловлена статусом этого актора в современном контексте государственной политики, дающим ему доступ к институциональным инструментам (вос)производства новой традиции, в первую очередь через возможность влиять на позицию федеральных и региональных властей. В то время как маргинализация феминистской повестки в официальной идеологии и слабая позиция феминистских организаций, выступающих против ограничения репродуктивных прав женщин, в поле публичной политики значительно снижает способность этих организаций выиграть в борьбе за определение традиции. В данной ситуации представители медицинского профессионального сообщества, а также Министерства здравоохранения, занимающие более умеренную позицию и не поддерживающие полный запрет абортов, выступают сдерживающей силой. Их аргументация не связана с морально-нравственными категориями и не претендует на переопределение смысловых значений этого репродуктивного выбора. Экспертная позиция связана с опасением, что полный запрет приведет к росту числа криминальных абортов и их негативным последствиям для здоровья женщин.

\section{ГОСУДАРСТВОМ ОРГАНИЗОВАННЫЕ НЕГОСУДАРСТВЕННЫЕ ОРГАНИЗАЦИИ (ГОНГО) КАК ПРОВОДНИКИ АНТИАБОРТНОЙ ПОВЕСТКИ}

Позиция государства как наиболее значимого политического актора, обладающего большим объемом различного рода ресурсов, является ключевой для определения

\footnotetext{
${ }^{16}$ Патриарх Кирилл ответил противникам вывода абортов из ОМС (2019). Regnum.ru, 30.01.2019. URL: https://regnum.ru/news/society/2562701.html

17 «Биополитика»: Оксана Пушкина раскритиковала проект приказа минздрава об ограничении прав женщин на аборты перечнем патологий (2020). Новая газета, 14.12.2020.

URL: https://novayagazeta.ru/news/2020/12/14/166411-biopolitika-oksana-pushkina-raskritikovala-proekt-prikazaminzdrava-ob-ogranichenii-prav-zhenschin-na-aborty-perechnem-patologiy

18 Минздрав: проект приказа о перечне медицинских показаний для аборта не отменяет прерывание беременности по желанию женщины (2020). Новая газета, 14.12.2020.

URL: https://novayagazeta.ru/news/2020/12/14/166431-minzdrav-proekt-prikaza-o-perechne-meditsinskihpokazaniy-dlya-aborta-ne-otmenyaet-preryvaniya-beremennosti-po-zhelaniyu-zhenschiny
} 
повестки, формирования и регламентации направлений деятельности НКО в сфере регулирования рождаемости. Государственная поддержка на идеологическом, институциональном и финансовом уровнях позволила в 1990-х - начале 2000-х годов создать сеть центров планирования семьи, разрабатывать программы сексуального образования подростков и молодежи В этот период в решении проблемы высокого уровня абортов также принимали участие НКО, получавшие поддержку от зарубежных фондов.

Начиная с середины 2000-х годов изменяются нормативно-правовые основания регулирования и финансирование деятельности НКО (например, организация Фонда Президентских грантов), в первую очередь в социальной сфере (Owen, Bindman 2017: 100). Наряду с этим были введены санкции за получение финансирования из ряда зарубежных источников, что привело к тому, что аффилиация с государством и РПЦ, получение финансирования из государственных и олигархических фондов по сути стала единственной возможной стратегией для сохранения деятельности НКО. Как было показано выше, антиабортная риторика как один ключевых инструментов пропаганды традиционных ценностей и «традиционной модели семьи» дает импульс для развития целого ряда консервативно-ориентированных организаций и инициатив. В научной литературе для обозначения подобных общественных организаций, созданных по инициативе и на деньги государства, используется аббревиатура ГОНГО/GONGO (Hasmath, Hildebrandt, Hsu 2019).

Одной из наиболее крупных и влиятельных ГОНГО, которые открыто заявляют о своей антиабортной позиции, является Фонд Апостола Андрея Первозванного, который с 2006 г. реализует программу «Святость материнства» ${ }^{19}$. Под ее эгидой проводятся регулярные форумы («Святость материнства», «Многодетная семья и будущее человечества»), в работе которых принимают участие представители федеральной и региональной властей, ведущих религиозных конфессий, НКО, выступающие в поддержку традиционных семейных ценностей. Тесное сотрудничество с властью позволяет сотрудникам программы участвовать в разработке политических документов в сфере семейной политики, например, вносить инициативы в концепцию семейной политики РФ, лоббировать введение программы «Семьеведение» в образовательные стандарты средней школы.

Одним из приоритетных проектов, реализуемых фондом, является программа «Ты не одна», ориентированная на поддержку женщин, «оказавшихся в силу жизненных трудностей в ситуации репродуктивного выбора». Данный проект ориентирован не только на работу с женщинами, его задача - обеспечить включение ставок психологов в учреждениях родовспоможения. С 2016 г. совместно с Министерством здравоохранения РФ фонд также проводит Всероссийский конкурс «Святость материнства», который ориентирован на специалистов - работников здравоохранения, психологов и социальных работников, выступающих против абортов. В конце каждого года подводятся итоги работы и награждаются победители конкурса: специалисты, которые смогли отговорить от абортов наибольшее число женщин. Так, в конкурсе 2018 г. приняли участие 300 человек из 60 регионов. В одной из номинаций победила социальный работник перинатального центра

19 Святость материнства. Фонд Апостола Андрея Первозванного http://fap.ru/programs/svyatost-materinstva/ (дата обращения 16.06.2021). 
в г. Тобольске, которая была награждена медалью «Святость материнства» за то, что смогла сделать так, чтобы 40 женщин, обратившихся в центр, решили сохранить беременность ${ }^{20}$.

Значительными финансовыми и административными ресурсами располагает Фонд социально-культурных инициатив (Президент Фонда - Светлана Медведева), который на протяжении ряда лет проводит акцию «Подари мне жизнь!» ${ }^{21}$. В рамках акции проводятся не только мероприятия просветительского характера, рассказывающие о вреде аборта, но поддерживаются региональные инициативы по введению моратория на операции по прерыванию беременности. Мораторий, как правило, приурочен к Дню семьи, любви и верности, который отмечается в России с 2008 г. Данная акция проводится при поддержке Министерства здравоохранения РФ.

Еще одним примером ГОНГО является общероссийское общественное движение «За жизнь!», которое сформировалось вокруг одноименного фестиваля, проходящего с начала 2010-х годов ${ }^{22}$. Территориально движение охватывает 103 региона, в него входят представители РФ, Украины, Белоруссии, а также Сербии. Главная цель движения - защита «жизни» и «семейных ценностей», под которой понимается борьба с абортами средствами пропаганды. Движение активно участвует в разработке и продвижении законопроектов по защите «жизни детей с момента зачатия». Важным направлением работы движения является противоабортное консультирование: убеждение женщин отказаться от прерывания беременности, подготовка специалистов, поддерживающих антиабортную позицию, распространение наглядных материалов о вреде абортов.

Крупной пропагандистской кампанией данного движения был сбор подписей в поддержку петиции о запрете абортов (9 февраля 2016 г., Инициатива №87Ф21245). Организаторы этой акции заявляют, что смогли собрать 1 млн подписей, в том числе получить одобрение главы РПЦ23, что позволяет им воспользоваться Указом Президента РФ от 4 марта 2013 г. №183 «О рассмотрении общественных инициатив, направленных гражданами Российской Федерации с использованием интернет-ресурса «Российская общественная инициатива» ${ }^{24}$. Согласно Указу такие петиции (с условием, что они размещались на сайте Российской общественной инициативы) должны рассматриваться специальными экспертными группами, рекомендующими их к рассмотрению соответствующим органом власти, в том числе Государственной думой. Однако на сайте Российской общественной инициативы, где опубликована данная петиция, указано, что собрано 100192 голоса «за» и 2972 голоса «против» 25 , вследствие чего эксперты

\footnotetext{
20 Тоболячка Инга Ягунова за 1,5 года отговорила от аборта 40 женщин (2018). Уральский меридиан. URL: https://ural-meridian.ru/news/89338/?fbclid=IwAR04epZ9VCXwtn5mm4LDV9W0gZM_9Nwc_uWdWT5A7m7xGYW_U6LkHjSA70

${ }^{21}$ Подари мне жизнь. Фонд социально-культурных инициатив. URL: http://www.fondsci.ru/projects/social/367/

22 Общероссийское общественное движение AHO «За жизнь». URL: https://rusprolife.ru

${ }^{23}$ Петиция в защиту детей до рождения. Общероссийское общественное движение АНО «За жизнь». URL: https://rusprolife.ru/petitsiya-za-zapret-abortov/

${ }^{24}$ Указ Президента РФ от 4 марта 2013 г. №183 «О рассмотрении общественных инициатив, направленных гражданами Российской Федерации с использованием интернет-ресурса "Российская общественная инициатива». URL: http://base.garant.ru/70326884/\#ixzz6xwgVCXUj

25 Оплата государством абортов только по медицинским показаниям. Российская общественная инициатива. URL: https://www.roi.ru/21245/
} 
правительства признали ее нецелесообразной, хотя и одобрили саму идею снижения количества абортов.

Другим примером продвижения антиабортной повестки с участием ГОНГО является учреждение благотворительным фондом «Женщины за жизнь» в декабре 2018 г. премии «Амбассадор защиты жизни до рождения» ${ }^{26}$. Это награда в виде значка, которой будут награждать тех, кто выступает против абортов. Одним из направлений деятельности фонда является проект «Спасенные»: «До спасения жизни может разделять одно слово. Ежедневно мы проводим интернет-мониторинг и находим женщин, которые думают об аборте. Под руководством перинатальных психологов волонтеры беседуют с такими женщинами, убеждая их оставить ребенка. Если нужна адресная помощьь, Фонд старается ёе оказать. Победы наших волонтеров - это решения в пользу жизни. Скриншоты с радостными вестями мы публикуем в наших соц. сетях» ${ }^{27}$. На сайте фонда нет информации о том, каким образом проводится поиск и мониторинг женщин, как проходит работа с ними, однако регулярно публикуются отчеты о проделанной работе, где можно узнать, что: «Спасено 46 младенцев за май. Всего спасено 2186 (июнь 2021 года)», а также пользователи могут поделиться «своей историей» о том, как женщины сохранили беременность благодаря фонду.

Рекламный ролик «Победили мы фашистов! Одолеем абортистов!» ${ }^{28}$, выпущенный осенью 2018 г. «Фондом семьи и демографии во имя святых Петра и Февронии» (ныне покойный, первый руководитель - протоиерей Дмитрий Смирнов), является показательным примером инициативы антиабортной пропаганды. Этот ролик интересен двумя характерными особенностями. Во-первых, в социальной рекламе, пропагандирующей рождаемость (например плакаты в московском метро «Стране нужны ваши рекорды»), единственным родителем является мать. Фигура отца не представлена ни на плакате, ни в ролике. По сути, мы можем говорить о современной версии советского гендерного контракта, когда материнство было социальной обязанностью женщины. Во-вторых, слоган данного рекламного ролика, а также символическая отсылка к атрибутике акции «Бессмертный полк», которая ежегодно проходит 9 мая во всех городах страны. Использование символики самого главного официального праздника современной России - Дня Победы, а также сравнение сторонников абортов с фашистами воспроизводит позицию власти (государства и церкви) по демографическим проблемам как проблему национальной безопасности, угроза которой приравнивается к угрозе потери страны в ходе Второй мировой войны.

Таким образом, антиабортная риторика начинает активно разворачиваться при помощи НКО, деятельность которых легитимируется и поддерживается государством и РПЦ. ГОНГО выступают проводниками консервативной идеологии, что позволяет им аккумулировать идеологические и материальные поддержки, вовлекая женщин в свои инициативы и создавая видимость поддержки населением традиционных семейных

\footnotetext{
${ }^{26}$ Премия фонда. Благотоврительный фонд «Женщинны за жизнь». URL: https://womenprolife.ru/projects/17

27 Сохрани в себе человека. Благотоврительный фонд “Женщины за жизнь”. URL: https://womenprolife.ru

${ }^{28}$ Победили мы фашистов! Одолеем абортистов! Youtube.

URL: https://www.youtube.com/watch?v=aqnSOL1rrzY
} 
ценностей. В своих пропагандистских кампаниях они используют мобилизационную военную риторику, призывая женщин отказаться от абортов для «спасения нации» и «достижения национальных интересов».

\section{ИНСТИТУЦИОНАЛЬНЫЕ СЕТИ ПОДДЕРЖКИ АНТИАБОРТНОЙ ПОЛИТИКИ НА РЕГИОНАЛЬНОМ УРОВНЕ}

В данном параграфе мы покажем, каким образом на уровне регионов формируются институциональные сети поддержки антиабортной политики как индикатора консервативной мобилизации, которая активно разворачивается в последние годы на национальном уровне. Улучшение приоритетных демографических показателей является для представителей региональных властей одним из показателей для оценки эффективности их деятельности. Кооперация исполнительной власти с консервативноориентированными акторами, в первую очередь с РПЦ, позволяет регионам не только проводить семейную политику, не противоречащую приоритетам, обозначенным на национальном уровне, но и аккумулировать дополнительные ресурсы для реализации подобных проектов. Для понимания того, как разворачивается консервативная мобилизация в современном российском обществе, как выстраивается антиабортная риторика и какие акторы участвуют в формировании и продвижении антиабортной повестки, мы анализируем ряд региональных инициатив, которые представляются наиболее показательными с точки зрения создания форм сотрудничества между государственными и религиозными органами.

Местные власти творчески подошли к разработке мер практической реализации решений Минздрава по профилактике абортов. Например, в Волгоградской области при Волгоградской епархии создали мобильную службу по предотвращению абортов, в которую входил священник и представители областных комитетов социальной защиты населения и здравоохранения. Задача службы состояла в том, чтобы оказывать помощь в пропаганде семейных ценностей, профилактике абортов и организовывать доабортное консультирование. Предполагалось, что сотрудники службы будут встречаться с главврачами медучреждений, в том числе женских консультаций и роддомов, а также семьями, принявшими решение об аборте, для того, чтобы отговорить (в первую очередь, женщин) от совершения этой медицинской процедуры. Вопрос, откуда сотрудники мобильной службы получают информацию о конкретных семьях, принимающих решение о прекращении беременности, не обсуждается ${ }^{29}$.

На Дальнем Востоке повышение уровня рождаемости и профилактика абортов являются приоритетными направлениями региональной демографической политики. Успешным регионом считается Хабаровск, где за год работы число женщин, отказавшихся от абортов, увеличилось на 22\%. Этот опыт оценивается как успешный, который

29 Лопатин В. (2019). В Волгоградской епархии создали мобильную службу по предотвращению абортов. НовостиВолгограда.ру, 04.02.2019. URL: https://novostivolgograda.ru/news/society/04-02-2019/v-volgogradskoyeparhii-sozdali-mobilnuyu-sluzhbu-po-predotvrascheniyu-abortov 
необходимо распространить и на другие регионы. Работа по профилактике абортов, по мнению О. Пономаревой - эксперта Комитета по вопросам семьи, женщин и детей Госдумы РФ, предполагает, во-первых, консультирование женщин, в том числе онлайн (вебинары), семейными психологами и другими специалистами. Во-вторых, «мониторинг среди сотрудников здравоохранения региона, которые принимают решения по демографической политике, в той или иной степени. Уверена, что среди них есть много тех, кто поддерживают высокий уровень толерантности к абортам. Если они считают, что это допустимо, то это мнение экстраполируется на других специиалистов. Нам нужно здесь активно работать, чтобы не допускать этого. Мы готовы оказать помощь и уверена, что через год мы уже увидим положительные результатыл» ${ }^{30}$.

В 2018 г. в трех регионах России ввели четырёхдневный мораторий (временный запрет) на проведение абортов ${ }^{31}$ : в Приморском крае - с 31 июля по 3 августа, в Якутии, в Рязанской области - с 9 по 15 июля. Подобная инициатива проходила в рамках акции «Подари мне жизнь!», устроенной Фондом социально-культурных инициатив Светланы Медведевой совместно с Минздравом РФ.

В Красноярске в женских консультациях реализуется проект «Врачи за жизнь», также направленный на профилактику абортов. В марте 2018 г. роддом №4 г. Красноярск получил грант на проведение семинаров, направленных на сохранение жизни, в рамках конкурса «Православная инициатива 2017-2018», проходящего под эгидой РПЦ. В конце декабря в краевом Минздраве прошло награждение победителей конкурса - врачей 15 женских консультаций, которые отговорили обратившихся к ним женщин от аборта. В качестве награды вручали ангела из бисера, сделанного школьниками. Количество наград соответствовало числу «спасенных жизней» ${ }^{32}$.

С 1 декабря 2018 г. в Пензенской области женщины, которые обратились за направлением на аборт по ОМС, должны пройти «комиссию» в составе главы района, заместителя по социальным вопросам, главного врача, психолога, а также представителей женских организаций. Итогом работы комиссии должно быть решение женщины сохранить беременность. Руководство области рассматривает это как работу, направленную на профилактику абортов и ссылается на «удачный» опыт Нижнеломовского района Пензенской области, где в 2018 г. прервать беременность решили 50 женщин, 20 из которых после работы комиссии отказались от аборта.

В конце января 2019 г. губернатор Пензенской области Иван Белозерцев пригрозил увольнением главам муниципалитетов в случае отказа проводить личные встречи с женщинами, которые хотят сделать аборт. По его словам, чиновники обязаны выяснить причину такого решения: «С каждой женщиной, заявивщей о своем решении прервать

\footnotetext{
${ }^{30}$ Сокращать число абортов на Колыме будут с помощью вебинаров и наблюдения за врачами (2018). MagadanMedia, 10.12.2018. URL: https://magadanmedia.ru/news/768149/?fbclid=IwAR3-uqVFlyW910SGoBbmQW8-kL4y0i2HKwoAQ8ZmzP1fvWqmXnBk22NSY8

${ }^{31}$ Мишина В. (2018). Мораторий на аборты объявлен в просветительских целях. Коммерсантъ, 138. URL: https://www.kommersant.ru/doc/3706048

${ }^{32}$ Организаторы проекта «Врачи за жизнь» награждают лучших врачей, которые мотивируют женщин к сохранению беременности (2018). Министерство здравоохранения Красноярского края, 21.12.2018. URL: https://kraszdrav.ru/news/7016
} 
беременность, должны встретиться и побеседовать главврач женской консультации, психолог, представительнищь активной женской общественности и в обязательном порядке - глава муниципального образования, чтобы выяснить причины такого решения. Если дело в тяжёлом материальном положении или плохих бытовых условиях, помочь найти выход» ${ }^{33}$.

В 2019 г. в Ижевске началась кампания по открытию противоабортных кабинетов на базе государственных медицинских учреждений. Данная форма работы с женщинами, решившими сделать аборт, разработана при поддержке министерства здравоохранения Удмуртии и Удмуртской епархии. После обращения к врачу женщины должны пройти консультацию в противоабортных кабинетах, где врачи-консультанты подберут формы и метод оказания помощи для сохранения беременности в зависимости от конкретной жизненной ситуации женщины: гуманитарная, юридическая, психологическая помощь, временное проживание, содействие в трудоустройстве ${ }^{34}$.

Подобные антиабортные компании можно встретить практически во всех российских регионах. Их анализ показывает, что на региональном уровне представители государственной власти тесно взаимодействуют с РПЦ, реализуя совместные антиабортные инициативы. При этом РПЦ выступает здесь в качестве партнера местных властей и идеологического куратора медицинских учреждений. В отличие от федерального уровня, где идеологический ландшафт является более разнообразным, на региональном уровне критика консервативной позиции РПЦ в отношении репродукции и семьи со стороны НКО и активистов мало заметна.

\section{ПОПЫТКИ НАУЧНОЙ ЛЕГИТИМАЦИИ АНТИАБОРТНОЙ ПОЛИТИКИ}

В целом в отечественном академическом дискурсе условно можно выделить две основные точки зрения по вопросам репродукции, которые вписаны в более широкий контекст оценки состояния и перспектив развития семьи. Условно можно выделить «алармистскую» и модернизационную точки зрения, представленные главным образом в работах таких авторов, как социолог семьи А. Антонов и демограф А. Вишневский соответственно. «Алармистская» позиция основана на представлении о том, что семья находится в состоянии глубокого кризиса. По мнению Антонова, произошедшая в стране трансформация семьи является частным выражением глобального мирового кризиса социального института семьи, который рассматривается как «пороки сощиальной организации рыночно-индустриального типа» (Антонов 2005: 579). Кризис семьи, одним из наиболее ярких показателей которого является снижение уровня рождаемости в том числе и в результате абортов, связывается с ослаблением социально-нормативной регуляции семейности, трансформацией культурных символов и образцов, снижением

\footnotetext{
${ }^{33}$ Пензенский губернатор обязал чиновников отговаривать женщин от абортов (2019). Интерфакс, 21.01.2019. URL: https://www.interfax.ru/russia/647023 (Дата обращения 26.03.2021).

${ }^{34}$ В Ижевске открылся первый кабинет противоабортного консультирования (2019). Udm-info.fu, 06.03.2019. URL: https://udm-info.ru/news/society/06-03-2019/v-izhevske-otkrylsya-pervyy-kabinet-protivoabortnogokonsultirovaniya
} 
ценности брака, семьи с детьми, внутрисемейного единства. «Модернизационная» позиция, напротив, утверждает, что трансформация брачно-репродуктивного поведения осуществляется в рамках более широкого процесса модернизации семьи и репродукции, «кризиса ее традиционной формыл», перехода к новому типу семьи (Вишневский 2006: 239). А. Вишневский полагает, что особых оснований, чтобы драматизировать нынешнюю «семейную» ситуацию в России, нет. В массовом демографическом поведении людей не наблюдается никаких чрезвычайных изменений, частота браков, разводов, уровень рождений остаются в границах колебаний, наблюдающихся уже не одно десятилетие, а число абортов, напротив, стремится к уменьшению.

Наиболее ярким примером академической легитимации антиабортной политики, представленной как инструмент достижения национальной безопасности, является статья академика РАН В. Жукова «Законодательство об абортах: мировые тренды и национальные интересы», вышедшая в 2018 г. в научном журнале «Социологические исследования» (Жуков 2018). Публикация данного текста вызвала большой резонанс в профессиональном сообществе, поставив под сомнение легитимность этого научного журнала, опубликовавшего на своих страницах столь одиозный текст. Критические замечания в адрес автора статьи и редакции журнала касались низкого научного качества текста, его откровенной идеологической ангажированности, а также самого факта публикации подобного высказывания на страницах научного издания. Однако сам текст статьи (ее название и содержание) является крайне показательным примером того, каким образом происходит артикуляция позиции «пролайф» в академическом дискурсе, в какую риторику помещается проблема запрета абортов в современной России: защиты национальных интересов.

Основной пафос этой статьи заключается в том, что аборт - это детоубийство, это зло XXI века. Автор критикует либеральное законодательство в области репродуктивных прав женщин, действующее в РФ, и пытается доказать, что запрет абортов приведет к однозначно положительным эффектам во всех областях социально-политической и экономической жизни общества. Более того, В. Жуков утверждает, что «дальнейшая либерализация законодательства может принести значительный ущерб социальнополитическому, финансовому, экономическому, демографическому, интеллектуальному развитию страны и повлиять на электоральное поведение населения (курсив-Ж.Ч., Л.Ш)» (Жуков 2018: 113). В этом отношении данная аргументация оперирует не только демографическими показателями, традиционными для сторонников запрета аборта, но и акцентирует прикладной характер данной проблемы: управление поведением граждан, потеря которого рассматривается им в качестве негативных последствий для власти с точки зрения возможности манипулирования общественным мнением и сохранения социальной базы поддержки правящего режима.

Пытаясь дать анализ мирового и российского законодательства, автор данной статьи однозначно защищает свою антиабортную позицию, выдвигает необоснованные утверждения и приводит ничем не подкрепленные статистические данные (Тимошенко 2019: 173). В частности, Жуков утверждает: «В мире делается более 50 млн абортов в год. Другими словами, в утробах потенциальных матерей ежегодно убивается столько же, сколько за 6 лет Второй мировой воины” (Жуков 2018: 113). Таким образом, автор вводит 
новую трактовку зарождения человеческой жизни, статуса эмбриона и пытается обосновать отсутствие у женщины права на совершение репродуктивного выбора.

Само сравнение данных о количестве абортов с числом жертв Второй мировой войны является крайне показательным для понимания того, каким образом в современном российском дискурсе конструируется проблема абортов. Начиная с 2000-х годов, демографические проблемы рассматривались сторонниками алармистской позиции в категориях национальной катастрофы, вымирания российской нации, что является типичным для официального дискурса государства ${ }^{35}$. Однако относительно недавно снижение рождаемости, которое видится сторонниками этой позиции исключительно как следствие абортов, стало определяться через апелляцию к Великой Отечественной войне, конструирование памяти о которой выступает несущим идеологическим мифом путинской идеологии. Сталинская политика по запрету абортов оценивается автором статьи как однозначно положительная, приведшая к победе над фашистской Германией: «Когда-то Геббельс пришел к выводу: Германия никогда не победит народ, у которого 90\% женщин сохраняет девственность до свадьбы. В советское время значительная часть семейных традиций сохранялась, беременность икольниц встречалась крайне редко и воспринималась как чрезвычайное происшествие и семьей, и школой, и общественностью» (Жуков 2018:115). Необходимо отметить, что сравнение сторонников права на аборт с фашистами является достаточно распространенным риторическим приемом, который используется в официальном дискурсе: выступлениях традиционалистов, пропаганде традиционных семейных ценностей (ролик социальной рекламы «Победили мы фашистов, одолеем абортистов»). В январе 2019 г. на встрече с сотрудниками и студентами медицинских вузов глава РПЦ сравнил женщин, которые сделали аборт по медицинским показаниям, с фашистами: «Убивая плод, который в чем-то неполноченен, мы убиваем инвалида. Так делал только Гитлер - у него жить должны были только здоровые. Подправлять человеческую расу только потому, что из эмбриона не получится хорочий акробат, - это преступление против человечности» ${ }^{36}$.

Аргументируя свою антиабортную позицию и необходимость законодательного ужесточения репродуктивных прав, Жуков пытается риторически «играть на правовом поле», ссылаясь на статьи Конституции РФ. Так, ст. 28 гарантирует гражданам свободу совести, включая право свободно иметь религиозные и иные убеждения и действовать в соответствии с ними. По мнению автора, это конституционное право систематически нарушается применительно к врачам-гинекологам: «Однако направление на аборт $u$

\footnotetext{
35 Так, в Послании Президента РФ Федеральному Собранию в 2000 г. было заявлено: «Нас, граждан России, из года в год становится все меньше и меньше. Уже несколько лет численность населения страны в среднем ежегодно уменьшается на 750 тысяч человек. И, если верить прогнозам, а прогнозы основаны на реальной работе, реальной работе людей, которые в этом разбираются, этому посвятили всю свою жизнь, уже через 15 лет россиян может стать меньше на 22 миллиона человек. Я прошу вдуматься в эту цифру: седьмая часть населения страны. Если нынешняя тенденция сохранится, выживаемость нации окажется под угрозой (курсив - Ж.Ч., Л.Ш). Нам реально грозит стать дряхлеющей нацией. Сегодня демографическая ситуация одна из тревожных» (Послание Президента РФ Федеральному Собранию от 15.01.2020 (2020). Консультант Плюс. URL: http://www.consultant.ru/document/cons_doc_LAW_342959/\#dst0).

36 «Только Гитлер убивал инвалидов!»: Патриах осудил аборты по причине физических недостатков (2019). Комсомольская правда, 29.01.2019. URL: https://www.kp.ru/daily/26933/3983819/
} 
производство аборта является трудовой обязанностью врачей-гинекологов (...) обучение и работа по специальностям «акушерство и гинекология» становится невозможной для людей, чьи убеждения не позволяют производить аборт по нравственным, религиозным, научным и иным убеждениям, ибо такие люди не получают возможности в полной мере реализовать конституционное право свободно распоряжаться своими способностями к труду, свободно выбирать род деятельности и профессию, что гарантирует ст. 37 Конституичии РФ» (Жуков 2018: 120).

В. Жуков считает, что именно государство должно принять меры по ужесточению доступа к процедуре аборта. При этом риторика, к которой прибегает автор, выдержана в рамках патерналистской семейной политики и этакратического гендерного порядка советского периода. Его позиция очень инструментальна по отношению к женщинам как демографическому ресурсу страны, мобилизация которого в очередной раз позволит преодолеть негативную демографическую ситуацию в России: «Если Правительство России, СМИ и общество примут меры, необходимые для того, чтобы поднять и на законодательном уровне закрепить авторитет женщины-матери, проявить государственную заботу о её потомстве, взять на себя ответственность за воспитание рожденного женщиной ребенка и воспитывать его в духе уважения кматери, принять ряд мер по снижению материнской и младенческой смертности, то количество абортов можно уменьшить в 2-3 раза. Дальнейтая арифметика проста: если спасти жизни хотя бы 1,5-2 млн человек, убедив женщчин отказаться от аборта, и прибавить к этому 1,5-1,9 млн ежегодно появляющихся на свет мальшей, то Россия выберется из демографической ямы, рост населения страны приобретет устойчивый характер, к 2025 г. в стране будет проживать 165 млн человек» (Жуков 2018: 122). Этот заключительный параграф статьи показателен с точки зрения артикуляции консервативной позиции, которую транслирует эксперт и которая находит отражение в официальной риторике государства относительно демографических проблем в целом. Автор видит государство как основного актора, способного определять репродуктивный выбор женщин. Достижение количественных показателей (нужная для государства численность населения) возможно исключительно через государственную заботу о женщине-матери.

В целом в академическом дискурсе существует поляризация взглядов на брачное и репродуктивное поведение. Консервативно-алармисткий подход не является доминирующим. При этом заметно его концептуальное и идеологическое совпадение с консервативным официальным дискурсом, транслируемым государством и РПЦ. Идеологическая кампания с целью возродить традиционные семейные ценности, борьба против абортов, гомосексуальности и феминизма в последнее время не просто набирает обороты, но и подкрепляется соответствующими экспертными высказываниями ученых, демонизирующими данные явления и рассматривающими их в качестве опасных для российского общества.

\section{ЗАКЛЮЧЕНИЕ}

Таким образом, консервативная мобилизация начинается на уровне федерального законодательства и выступлений представителей центральной власти. Содержательно эти 
инициативы связаны с декларацией демографических проблем и сокращения численности населения как угрозы национальной безопасности. Они нацелены на регулирование поведения граждан в сфере интимности, их телесности и «морального облика». По мнению М. Фуко, интерес политической власти к здоровью, репродукции и демографическим характеристикам населения связан с трансформацией форм власти и управления в современных обществах. Проводниками этой власти выступают эксперты, СМИ и различные формы самоуправления на местах. Фуко называет такие формы контроля биовластью. Под биовластью понимаются техники нормализации и мониторинга человеческих тел, имеющие своей целью сделать их более послушными и продуктивными (Foucault 2003). Управление через медиа, социальную политику, образование, здравоохранение имеет имплицитный интерес в формировании индивидов особого типа (Lawler 2000: 2). Такие индивиды действуют не на основе внешнего директивного контроля, но могут управлять своим поведением самостоятельно, ориентируясь на заданные образцы нормальности. В этом смысле конечной целью консервативной мобилизации являются управляемые российские граждане, индоктринированные идеологией семейного образа жизни и многодетности. При этом основной пафос дискурса консервативной мобилизации, связанный с проблематикой абортов, направлен на женщин. Данный дискурс представляет женщин как ответственных за уровень рождаемости, воспроизводство нации и национальную безопасность (Rivkin-Fish 2010). Он направлен на контроль женской телесности и сексуальности через превращение их в «моральных субъектов», которые подчиняют свое поведение национальным интересам (Paxon 2004). Поскольку данные интересы формулируются в категориях (без)опасности, защиты интересов нации, т. е. используют милитаристскую терминологию, фактически дискурс о праве на аборт становится формой идеологического производства патриархатного гендерного порядка (Connell 1987).

Смена позиции государства относительно абортов наиболее четко прослеживается, начиная с середины 2000-х годов, когда консервативная риторика становится доминирующей, а также усиливается изменением законодательства, регулирующего различные сферы: семейной политики, защиты детства, здравоохранения, условий деятельности НКО. При этом основные идеологические дебаты на федеральном уровне ведутся вокруг сохранения/исключения процедур медицинского прерывания беременности из плана ОМС. Многочисленные законодательные инициативы депутатов ГД, с которыми солидаризируются в своих публичных высказываниях представители РПЦ и православноориентированные эксперты (например, выступления уролога и специалиста по репродуктивному здоровью, члена-корреспондента РАН, профессора О. Аполихина), не находят поддержки со стороны Министерства здравоохранения и отклоняются. Тем не менее вся совокупность высказываний, инициатив, а также региональных кампаний может рассматриваться как консервативная мобилизация, направленная на преодоление «проблемы низкой рождаемости» за счет пропаганды традиционных семейных ценностей и снижения толерантности к абортам. В продвижение антиабортной повестки активно включаются различные акторы (представители федеральной и региональной власти, профильные $\mathrm{HKO}$, представители РПЦ), что позволяет им включаться в институционализированные сети поддержки и получать доступ к финансированию в 
рамках соответствующих программ (например, программа, направленная на сокращение числа абортов в рамках Десятилетия детства). Таким образом, консервативная мобилизация предполагает не только оформление идеологической рамки, но и выработку институциональных механизмов ее реализации.

\section{БЛАГОДАРНОСТИ}

Выражаем благодарность анонимным рецензентам за внимательное чтение текста, ценные замечания и комментарии, позволившие существенно улучшить текст статьи. Эта работа в большой степени была вдохновлена работами А.Г. Вишневского, его научной и личной позицией в отношении изучаемой проблематики.

\section{ЛИТЕРАТУРА}

Антонов А. (Ред.) (2005). Социология семьи: Учебник. 2-е изд., перераб. и доп. М.: ИнфраM.

Antonov A. (Ed.) (2005). Sotsiologiya sem'i: Uchebnik. 2-e izd., pererab. i dop. Moscow: InfraM. (In Russ.).

Бек У. (2000). Общество риска. На пути к другому модерну. Пер. с нем. В. Седельника и Н. Фёдоровой. М.: Прогресс-Традиция.

Bek U. (2000). Obshchestvo riska. Na puti k drugomu modernu. Per. s nem. V. Sedel'nika i N. Fëdorovoy. M.: Progress-Traditsiya. (In Russ.).

Вишневский А. (Ред.) (2006). Демографическая модернизаџия России, 1900-2000. М.: Новое издательство.

Вишневский А. (2012а). Демографический прорыв или движение по кругу? Часть первая. Демоскоп Weekly, 533-534. URL: http://www.demoscope.ru/weekly/2012/0533/tema01.php

Вишневский А. (2012b). Демографический прорыв или движение по кругу? Часть вторая. Демоскоп Weekly, 535-536. URL: http://www.demoscope.ru/weekly/2012/0535/tema01.php

Вишневский А.Г., Денисов Б.П., Сакевич В.И. (2017). Контрацептивная революция в России. Демографическое обозрение, 1, 6-34.

Вишневский А., Захаров С. (2019). Заключение. В Захаров С. (Отв. ред.), Население России 2017: двадиать пятый ежегодный демографический доклад (сс. 459-447). М.: Издательский дом НИУ ВШЭ.

Гидденс Э. (2004). Трансформащия интимности. Сексуальность, любовь и эротизм в современных обществах, пер. с англ. В. Анурина. СПб.: Питер.

Захаров С. (2012). Какой будет рождаемость в России? Демоскоn Weekly, 495-496. URL: http:// demoscope.ru/weekly/2012/0495/tema01.php.

Здравомыслова Е., Темкина А. (2003). Советский этакратический гендерный порядок. В Пушкарева Н.М. (Ред.), Социальная история. Социальная история ежегодник. Женская и гендерная история (сс 436-463). М.: РОССПЭН.

Жуков В. (2018). Законодательство об абортах: мировые тренды и национальные интересы. Социологические исследования, 3, 113-123. 
Магун А. (2010) Перестройка как консервативная революция? Неприкосновенный запас, 6(74). URL: https://magazines.gorky.media/nz/2010/6/perestrojka-kak-konservativnayarevolyucziya.html

Муравьёва М. (2014). Традиционные ценности и современные семьи: правовые подходы к традиции и модерну в современной России. Журнал исследований социальной политики, 12(4), 625-638.

Печерская Н. (2012). Мифология родительства: анализ дискурсивного производства идеальной семьи. Журнал исследований социальной политики, 10 (3), 323-342.

Роткирх А., Темкина А. (2007). Советские гендерные контракты и их трансформация в современной России. В Здравомыслова Е., Темкина А. (Ред.), Российский гендерныий порядок: социологический подход (сс. 169-200). СПб: Изд-во Европейского университета в Санкт-Петербурге.

Сакевич В., Денисов Б., Ривкин-Фиш М. (2016). Непоследовательная политика в области контроля рождаемости и динамика уровня абортов в России. Журнал исследований сочиальной политики, 14(4), 461-478.

Тимошенко А. (2019). Письмо в редакцию. Социологические исследования, 4, 173-174.

Чернова Ж. (2012b). Баланс семьи и работы: политика и индивидуальные стратегии матерей. Журнал исследований социальной политики, 10 (3), 295-308.

Шпаковская Л. Л. (2013). Дискурсивные практики родительства: политические вызовы и актуальные проблемы. Вестник Томского государственного университета. Философия. Соичология. Политология, 1, 236-249.

Шпаковская Л. Л. (2012). Политика институционализации и практики приватизации семейной жизни: партнерство и брак в России. Журнал исследований социальной политики, 10(3), 309-323.

Ярская-Смирнова Е. (2010). «Да-да, я вас помню, вы же у нас неблагополучная семья!» Дискурсивное оформление современной российской политики. Женщина в российском обществе, 2, 14-25.

Chernova Zh. (2012a). New Pronatalism? Family Policy in Post-Soviet Russia. REGION: Regional Studies of Russia, Eastern Europe, and Central Asia, 1(1), 75-92.

Connell R. (1987). Gender and power: society, the person and sexual politics. Stanford: Stanford University Press.

Flick U. (2006). An Introduction to Qualitative Research. London: Sage Publications.

Foucault M. (2003). The Birth of Biopolitics. The Essential Foucault: Selections from Essential Works of Foucault 1954-1984, 202-207. London: The New Press.

Giddens A. (1991). Modernity and Self-Identity: Self and Society in Late Modern Age. Cambridge: Polity Press.

Graff A., Ratna K., Walters S. (2019). Introduction: Gender and the Rise of the Global Right. Signs: Journal of Women in Culture and Society, 44(3), 541-60.

Hasmath R., Hildebrandt T., Hsu J. (2019). Conceptualizing government-organized nongovernmental organizations. Journal of civil society, 15(3), 267-284.

Illouz E. (2008). Saving the Modern Soul: Therapy, Emotions, and the Culture of Self-Help.

Oakland: University of California Press. 
Lawler St. (2000). Mothering the Self: Mothers, Daughters, Subjects. London: Routledge.

Owen C., Bindman E. (2017). Civic Participation in a Hybrid Regime: Limited Pluralism in Policymaking and Delivery in Contemporary Russia. Government and Opposition, 54(1), 98120.

Paxon H. (2004). Making modern mothers: ethic and family planning in urban Greece. Berkley, Los Angeles: University of California Press.

Rivkin-Fish M. (2010). Pronatalism, Gender Politics, and the Renewal of Family Support in Russia: Towards a Feminist Anthropology of 'Maternity Capital. Slavic Review, 69(3), 701724.

Rivkin-Fish M. (2013). Conceptualizing Feminist Strategies for Russian Reproductive Politics: Abortion, Surrogate Motherhood, and Family Support After Socialism. SIGNS, 38(3), 569593.

Roche S. (2016). A Sound Family for a Healthy Nation: Motherhood in Tajik National Politics and Society. Nationalities Papers, 44(2): 207-224. doi:10.1080/00905992.2015.1087486

Van de Kaa D.J. (1987). Europe's Second Demographic Transition. Population Bulletin, 42, 159.

Vishnevsky A., Sakevich V., Denisov B. (2018). The contraceptive revolution in Russia. Demographicheskoe obozrenie, Vol. English selections 2017, 86-108.

Yuval-Davis N. (1997). Gender and Nation. London: Thousand Oaks: Sage. 


\title{
THE ANTI-ABORTION AGENDA IN THE CONSERVATIVE DISCOURSE IN RUSSIA: IDEOLOGICAL CAMPAIGNS, LEGAL INITIATIVES AND REGIONAL PRACTICES
}

\author{
ZHANNA CHERNOVA, LARISA SHPAKOVSKAYA
}

\begin{abstract}
The article examines the processes of conservative mobilization in Russia in 2000-2010s as a deployment of ideological propaganda campaigns using the conservative rhetoric of the traditional family, traditional values, and traditional gender roles in order to solve "demographic problems", above all the increase of fertility. The main focus of the article is the discourse on abortion. State anti-abortion propaganda is viewed as a "litmus test" of the ongoing processes of retraditionalization of state ideology and of instruments for regulating reproduction and sexuality. In analyzing the legislative and regional initiatives of the period under study, the authors describe the main public actors of the regional and federal levels, as well as the rhetoric they use. The article shows that since the 2000s one of the leading actors working for the adoption of antiabortion legislation has been the Russian Orthodox Church. At the same time, there have been public actors at the federal level who have held back the adoption of anti-abortion legislation and have been consistently critical of anti-abortion rhetoric. At the same time, on the regional level, pro-conservative mobilization actors have effectively used state support, without encountering noticeable criticism. Substantively antiabortion rhetoric is inscribed in the discourse on demographic problems and population decline as a threat to national security. It is aimed at regulating the behavior of citizens in the field of intimacy, their bodies, and morality, thus representing a variant of biopolitics in the terms of Michel Foucault. In this sense, the ultimate goal of conservative mobilization is to create docile citizens indoctrinated with the ideology of a traditional family lifestyle and large families.
\end{abstract}

Key words: anti-abortion rhetoric, conservatism, fertility, traditional family values, discourse analysis

Zhanna Chernova (chernova3o@mail.ru), The Sociological Institute of THE RAS - BRANCh OF THE FEDERAL

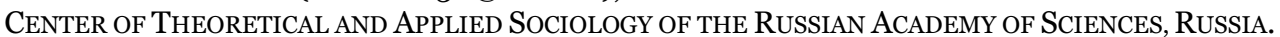

LARISA SHPAKOVSKAYA (slarisalarisa@gmail.com), THE SOCIOLOGICAL INSTITUTE OF THE RAS - BRANCH OF THE FEDERAL CENTER OF THEORETICAL AND APPLIED SOCIOLOGY OF THE RUSSIAN ACADEMY OF SCIENCES, RUSSIA.

DATE RECEIVED : APRIL 2021.

\section{REFERENCES}

Antonov A. (Red.) (2005). Sotsiologiya sem 'i: Uchebnik. 2-e izd., pererab. i dop. Moscow: InfraM. (In Russ.).

Bek U. (2000). Obshchestvo riska. Na puti k drugomu modernu. MOSCOW: ProgressTraditsiya. (In Russ.).

Chernova Zh. (2012a). New Pronatalism? Family Policy in Post-Soviet Russia. REGION: Regional Studies of Russia, Eastern Europe, and Central Asia, 1(1), 75-92. (In Russ.).

Chernova Zh. (2012b). Balans sem'i i raboty: politika i individual'nyye strategii materey. Zhurnal issledovaniy sotsial'noy politiki, 10(3), 295-308.

Connell R. (1987). Gender and power: society, the person and sexual politics. Stanford: Stanford University Press.

Flick U. (2006). An Introduction to Qualitative Research. London: Sage Publications. 
Foucault M. (2003). The Birth of Biopolitics. In The Essential Foucault: Selections from Essential Works of Foucault 1954-1984 (pp. 202-207). London: The New Press.

Giddens A. (1991). Modernity and Self-Identity: Self and Society in Late Modern Age. Cambridge: Polity Press.

Giddens A. (2004). Transformatsiya intimnosti. Seksual'nost', lyubov' i erotizm v sovremennykh obshchestvakh. Saint-Petersburg: Piter. (In Russ.).

Graff A., Ratna K., Walters S. (2019). Introduction: Gender and the Rise of the Global Right. Signs: Journal of Women in Culture and Society, 44(3), 541-60.

Hasmath R., Hildebrandt T., Hsu J. (2019). Conceptualizing government-organized nongovernmental organizations. Journal of civil society, 15(3), 267-284.

Illouz E. (2008). Saving the Modern Soul: Therapy, Emotions, and the Culture of Self-Help. Oakland: University of California Press.

Lawler St. (2000). Mothering the Self: Mothers, Daughters, Subjects. London: Routledge.

Magun A. (2010). Perestroyka kak konservativnaya revolyutsiya? Neprikosnovennyy zapas, 6(74). (In Russ.). URL: https://magazines.gorky.media/nz/2010/6/perestrojka-kakkonservativnaya-revolyucziya.html

Murav'yova M. (2014). Traditsionnyye tsennosti i sovremennyye sem'i: pravovyye podkhody k traditsii i modernu v sovremennoy Rossii. The Journal of Social Policy Studies, 12(4), 625638. (In Russ.).

Owen C., Bindman E. (2017). Civic Participation in a Hybrid Regime: Limited Pluralism in Policymaking and Delivery in Contemporary Russia. Government and Opposition, 54(1), 98120.

Paxon H. (2004). Making modern mothers: ethic and family planning in urban Greece. Berkley, Los Angeles: University of California Press.

Pecherskaya N. (2012). Mifologiya roditel'stva: analiz diskursivnogo proizvodstva ideal'noū sem'i. Zhurnal issledovanǐ̌ sotsial'noř politiki, 10(3), 323-342. (In Russ.).

Rivkin-Fish M. (2010). Pronatalism, Gender Politics, and the Renewal of Family Support in Russia: Towards a Feminist Anthropology of 'Maternity Capital. Slavic Review, 69(3), 701724.

Rivkin-Fish M. (2013). Conceptualizing Feminist Strategies for Russian Reproductive Politics: Abortion, Surrogate Motherhood, and Family Support After Socialism. SIGNS, 38(3), 569593.

Roche S. (2016). A Sound Family for a Healthy Nation: Motherhood in Tajik National Politics and Society. Nationalities Papers, 44(2), 207-224. doi:10.1080/00905992.2015.1087486

Rotkirkh A., Temkina A. (2007). Sovetskiye gendernyye kontrakty i ikh transformatsiya v sovremennoŭ Rossii. In Zdravomyslova E., Temkina A. (Red.) Rossiǔskiŭ genderny poryadok: sotsiologicheskiı̆ podkhod (pp. 169-200). Saint-Petersburg: Izd-vo Evropeĭskogo universiteta v Sankt-Peterburge. (In Russ.).

Sakevich V., Denisov B., Rivkin-Fish M. (2016). Neposledovatel'naya politika v oblasti kontrolya rozhdayemosti i dinamika urovnya abortov v Rossii. Zhurnal issledovaniy sotsial'noy politiki, 14(4), 461-478. (In Russ.). 
Shpakovskaya L.L. (2013). Diskursivnyye praktiki roditel'stva: politicheskiye vyzovy i aktual'nyye problemy. Vestnik Tomskogo gosudarstvennogo universiteta. Filosofiya. Sotsiologiya. Politologiya, 1, 236-249. (In Russ.).

Shpakovskaya L.L. (2012). Politika institutsializatsii i praktiki privatizatsii semeynoy zhizni: partnerstvo i brak v Rossii. Zhurnal issledovaniy sotsial'noy politiki, 10(3), 309-323. (In Russ.).

Timoshenko A. (2019). Pis'mo v redaktsiyu. Sotsiologicheskiye issledovaniya, 4, 173-174. (In Russ.).

Van de Kaa D.J. (1987). Europe's Second Demographic Transition. Population Bulletin, 42, 159.

Vishnevskiy A. (Red.) (2006). Demograficheskaya modernizatsiya Rossii, 1900-2000. Moscow: Novoye izdatel'stvo. (In Russ.).

Vishnevskiy A. (2012a). Demograficheskiy proryv ili dvizheniye po krugu? Chast' pervaya. Demoskop Weekly, 533-534. (In Russ.).URL: http://demoscope.ru/weekly/2012/0533/tema01.php

Vishnevskiy A. (2012b). Demograficheskiy proryv ili dvizheniye po krugu? Chast' vtoraya. Demoskop Weekly, 535-536. (In Russ.).URL: http://demoscope.ru/weekly/2012/0535/tema01.php

Vishnevskiy A.G., Denisov B.P., Sakevich V.I. (2017). Kontratseptivnaya revolyutsiya v Rossii. Demograficheskoye obozreniye, 1, 6-34. (In Russ.).

Vishnevsky A., Sakevich V., Denisov B. (2018). The contraceptive revolution in Russia. Demographicheskoe obozrenie, Vol. English selections 2017, 86-108.

Vishnevskiy A., Zakharov S. (2019). Zaklyucheniye. V Zakharov S. (Ed.), Naseleniye Rossii 2017: dvadtsat' pyatyy ezhegodnyy demograficheskiy doklad (pp. 459-477). Moscow : Izdatel'skiy dom NIU VShE. (In Russ.).

Yarskaya-Smirnova E. (2010). «Da-da, ya vas pomnyu, vy zhe u nas neblagopoluchnaya sem'ya!» Diskursivnoye oformleniye sovremennoŭ rossiǔskoĭ politiki. Zhenshchina v rossiǐskom obshchestve, 2, 14-25. (In Russ.).

Yuval-Davis N. (1997). Gender and Nation. London: Thousand Oaks: Sage.

Zakharov S. (2012). Kakoĭ budet rozhdayemost' v Rossii? Demoskop Weekly, 495-496. (In Russ.). URL: http:// demoscope.ru/weekly/2012/0495/tema01.php

Zdravomyslova E., Temkina A. (2003). Sovetskiı̆ etakraticheskiı̆ gendernyǐ poryadok, V: Pushkareva N.M., (Ed.), Sotsial'naya istoriya. Sotsial'naya istoriya ezhegodnik. Zhenskaya $i$ gendernaya istoriya (pp. 436-463). Moscow: ROSSPEN. (In Russ.).

Zhukov V. (2018). Zakonodatel'stvo ob abortakh: mirovyye trendy i natsional'nyye interesy. Sotciologicheskie issledovamia, 3, 113-123. (In Russ.). 